Participative Journal: Jurnal Pengabdian Pada Masyarakat

Vol. 01, No. 02, September 2021 | Page 71-81

E-ISSN 2776-2971, P-ISSN 2776-5954

Journal homepage: https://jurnal.jurmat.com/index.php/pj/index

\title{
Dampak bantuan langsung tunai bagi masyarakat akibat Covid-19 di Desa Malaka Kecamatan Pemenang Kabupaten Utara
}

\author{
Fadila Aulia ${ }^{1 *}$ \\ * Affiliasi: Prodi Ilmu Al-Qur'an dan Tafsir Universitas Islam Negeri Mataram"
}

\section{Keywords:}

BLT, Village Fund; Assistance

Kata kunci: Bantuan, BLT, Dana Desa
A b s t r a c t: The end of 2019 to be precise at the beginning of 2020 . The Covid-19 pandemic has become a problem all over the world. The entire government is overwhelmed but continues to try to overcome the spread of the Covid-19 virus while at the same time overcoming the various impacts of one of the impacts caused by the Covid-19 pandemic. This is an economic factor. In Indonesia, due to the pandemic, the community's economy has declined. And to overcome this, the government has made one of the efforts to reduce the burden on the community, namely refocusing the budget from various existing budget posts. And one of the the budget posts that was refocused was the Village Fund, the Village Fund which was actually intended for village development and development but was transferred to a cash transfer fund called Direct Cash Assistance (BLT). In the implementation of this program, in terms of the impact of the Direct Cash Assistance (BLT) program, many question are asked. This research was conducted in Malaka Village, Pemenang District, Nort Lombok Regency. The research finding show that the impact of this program, especially for the poor, is very beneficial for them, and some people very supportive of the program carried out by the central government.

A b s t r a k: Akhir tahun 2019 tepatnya pada Awal tahun 2020, pandemi Covid19 menjadi masalah di seluruh dunia. Seluruh pemerintahan kewalahan namun terus berupaya mengatasi penyebaran virus Covid-19 ini, sekaligus mengatasi berbagai dampak, salah satu dampak yang di timbulkan oleh pandemic Covid19 ini ialah faktor perekonomian. Di Indonesia, akibat pandemi perekonomian masyarakat menjadi menurun. Dan untuk mengatasi hal tersebut, pemerintah melakukan salah satu upaya untuk mengurangi beban masyarakat yaitu melakukan refocusing anggaran dari berbagai pos anggaran yang ada. Dan salah satu pos anggaran yang dilakukan refocusing adalah Dana Desa. Dana desa yang sebenarnya diperuntukkan untuk pembangunan dan pengembangan desa, namun dialihkan menjadi dana bantuan tunai yang dinamakan dengan Bantuan Langsung Tunai (BLT). Dalam implementasinya program ini dari sisi dampak

\footnotetext{
${ }^{1}$ Coresponden to author: Prodi Ilmu Al Qur'an dan Tafsir Fakultas Ushuluddin dan Studi Agama, Universitas Islam Negeri Mataram, Jl. Gajah Mada Jempong, Indonesia. (83116), e-mail addresses: 180601099.mhs@uinmataram.ac.id.
} 
dari program Bantuan Langsung Tunai banyak mengundang pertanyaan. Penelitian ini dilakukan di Desa Malaka Kecamatan Pemenang Kabupaten Lombok Utara. Temuan penelitian menunjukkan dampak program ini khususnya bagi masyarakat miskin yang sangat bermanfaat bagi mereka, dan sebagian masyarakat sangat mendukung program yang dilakukan oleh pemerintah pusat.

\section{Pendahuluan}

Kegiatan pengabdian kepada masyarakat atau Kuliah Kerja Partisipatif (KKP) merupakan salah satu Mata Kuliah yang wajib dilakukan oleh seluruh mahasiswa yang sudah menempati semester 6 yang memasuki semester 7 . Akan tetapi di tahun sekarang namanya sedikit di ubah menjadi Kuliah Kerja Partisipatif Dari Rumah (KKP-DR) Hal tersebut tidak merubah implementasi dari fungsi dan tujuan penyelenggaraan Perguruan Tinggi sebagaimana yang tercantum pada pasal 4 dan 5 UU Republik Indonesia Nomor 12 Tahun 2012 tentang Pendidikan Tinggi, bahwa; perguruan tinggi berfungsi mengembangkan kemampuan membentuk watak serta peradaban bangsa dengan tujuan terwujudnya Pengabdian kepada Masyarakat berbasis penalaran dan karya penelitian yang bermanfaat dalam memajukan kesejahteraan umum dan mencerdaskan kehidupan bangsa.

Dampak sosial dan ekonomi yang di akibatkan pandemi Covid-19 sangat berpengaruh bagi tingkat kesejahteraan masyarakat. Hal ini disebabkan adanya pembatasan kegiatan ekonomi yang secara makro menurunkan pertumbuhan ekonomi dan menyebabkan banyak orang kehilangan pekerjaan sehingga berpotensi meningkatkan jumlah masyarakat miskin.

Pemerintah telah merancang berbagai kebijakan baru dalam rangka menekan penyebaran dan penanganan virus ini. Salah satunya di terbitkannya peraturan pemerintah pengganti UU Nomor 1 Tahun 2020 tentang Kebijakan Keuangan Negara dan Stabilitas Sistem Keuangan untuk Penanganan Pandemi Corna Virus Disease (COVID-19) Dan/Atau Dalam Rangka Menghadapi Ancaman yang Membahayakan Perekonomian Nasional dan/atau Stabilitas Sistem Keuangan Menjadi Undang-Undang ${ }^{2}$.

Pandemi Covid-19 mempengaruhi beberapa aspek kehidupan, termasuk aspek ekonomi, di tingkat global. Sebagian besar sector industri mengalami penurunan, terutama di sector pariwisata dan daya beli masyarakat pun ikut menurun. Untuk mengurangi dampak negative pandemi Covid-19 terhadap perekonomian nasional, pemerintah Indonesia menerapkan beberapa program untuk menguatkan perlindungan sosial dan untuk memabntu perekonomian,

\footnotetext{
${ }^{2}$ Kemendes PDT'T. Panduan Pendataan Bantaun Langsung Tunai-Dana Desa (BLT-Dana Desa). Jakarta. 2020
} 
di antaranya: Program Keluarga Harapan (PKH), Bantuan Sosial Tunai (BST), Bansos. Sebagian besar dari program-program yang telah rutin di lakukan pemerintah. Terkait dengan Covid-19, pemerintah kemudian meningkatkan jumlah penerima bantuan dari program-progrma yang telah ada.

Program bantuan sosial pemerintah kepada masyarakat telah mengalami perubahan dan penjangkauan lebih banyak penerima. Program Bantuan Langsung Tunai (BLT) diadakan untuk mengganti subsidi BBM. Untuk mengurangi dampak negative dari pandemi Covid-19 terhadap perekonomian masyarakat, pemerintah melalui Kemensos telah menerapkan berbagai program bantuan sosial.

\section{Metode}

Kuliah Kerja Partisipatif UIN Mataram secara umum dilaksanakan berbasis desa setempat, bermakna bahwa mahasiswa melaksananakan KKP di Desa masing-masing yang diistilahkan dengan Kuliah Kerja Partisipatif-Dari Rumah (KKP-DR), dengan pertimbangan kondisi pembatasan intraksi dan agar menjamin keberterimaan masyarakat atas program yang akan dilaksanakan oleh peserta KKP-DR untuk mencapai tujuan pelaksaan KKP-DR berkaitan dengan Bantuan Langsung Tunai (BLT) di Desa Malaka Kecamatan Pemenang Kabupaten Lombok Utara NTB. Mahasiswa UIN Mataram melaksanakan seluruh programnya dengan metode kualitatif: 1) Partisipatif action yaitu ikut berpartisipasi untuk mensukseskan kegiatan yang ada di Desa Malaka, 2) Wawancara masyarakat sekitar Desa Malaka

\section{Hasil dan Pembahasan}

Desa Malaka Kecamatan Pemenang merupakan sebuah wilayah di Kabupaten Lombok Utara Nusa Tenggara Barat. Desa Malaka terdiri dari 12 Dusun yang memiliki kawasan wisata yang menarik terutama di sepanjang Pantai Desa Malaka. Kawasan wisata alam Desa Malaka terletak di pesisir pantai, yang mana wisatawan yang akan berkunjung ke daerah Gili Trawangan ataupun Bali secara otomatis melewati daerah ini, sehingga menjadi peluang untuk memikat wisatawan berkunjung ke daerah wisatawa Desa Malaka sebelem menyebrang menuju Gili Trawangan maupun Bali.

Kawasan wisata alam Desa Malaka sangat berpotensi untuk kemajuan pariwisata di Lombok Utara, bahkan ada beberapa potensi yang ada seperti Lapak Ikan Bakar di Dusun Nipah dan Dusun Pandanan. Tidak hanya itu, masih ada beberapa potensi lain di Desa Malaka yang sanggup menjadi icon Pariwisata Lombok Utara. Di Desa Malaka juga memiliki tempat wisata alam Desa Malaka yang banyak rekreasi keluarga yang bernuansa air atau pantai. Dengan adanya rekreasi di wisata alam Desa Malaka di wilayah Lombok Utara bisa menjadi salah satu alternative wisata di Lombok Utara yang bernuansa alam yang masih alami. 
Akan tetapi dengan adanya situasi saat ini Negara-negara di dunia sedang dilanda oleh pandemi Covid-19 termasuk Negara yang kita tempati yaitu Negara Indonesia. Pada akhir tahun 2019 merupakan tahun yang penuh kejutan bagi semua Negara di belahan dunia. Hal ini di sebabkan karena menyebarnya wabah penyakit atau virus yang bernama Covid-19 yang awalnya berkemang di Wuban, Negara Cina. World Health Organization (WHO) menyatakan wabah penyebar virus ini sebagai pandemic dunia saat ini. Hal ini juga di alami oleh Negara Indonesia.

Dengan adanya Covid-19 ini segala kegiatan yang dilakukan secara tatap muka dan mengundang kerumunan diistirahatkan untuk sementara waktu sampai waktu yang belum diketahui, termasuk juga dalam dunia pendidikan. Contohnya, mahasiswa yang sedang melaksanakan kegiatan KKP, di karenakan pandemic Covid-19 yang berlangsung pihak kampus mengambil kebijakan dengan melakukan KKP di rumah masing-masing, biasa di sebut dengan istilah KKP-DR (Kuliah Kerja Partisipatif-Dari Rumah).

Kuliah Kerja Partisipatif (KKP) merupakan kegiatan yang di lakukan oleh mahasiswa semester 6 yang memasuki semester 7. Kuliah Kerja Partisipatif (KKP) merupakan bentuk interaksi langsung antara mahasiswa dengan masyarakat sebagai perpanjangan tangan kampus serta sebagai latihan bagi mahasiswa untuk melihat secara langsung dan menerapkan ilmu pengetahuan yang di dapatkan ketika di kampus.

Secara umum tujuan dari kegiatan KKP-DR ini adalah bertujuan untuk meningkatkan kemampuan Sumber Daya Manusia (SDM) dalam memenuhi kebutuhan masyarakat dan memecahkan masalah yang dihadapi bersama di tengah masyarakat dalam rangka meningkatkan kesejahteraan sosial, pencerahan, dan pembebasan sesuai dengan visi, misi, dan fungsi Perguruan Tinggi Agama Islam.

Program kegiatan yang dilakukan oleh Mahasiswa dalam kegiatan KKP-DR ini disesuaikan dengan kebutuhan di lokasi KKP itu sendiri. Salah satunya yaitu tentang bagaimana kita menjadi Mahasiswa iku berperan penting dalam penyaluran bantuan dari Desa salah satunya ialah penyaluran Bantuan Langsung Tunai (BLT) Dana Desa. Bantuan Langsung Tunai (BLT) Dana Desa merupakan respon pemerintah dalam meminimalisir dampak Covid-19 bagi masyarakat yang di Desa terutama di berikan kepada msyarakat miskin.

Pemerintah sendiri telah melakukan berbagai upaya untuk menekan berbagai dampak yang dirasakan masyarakat oleh pandemi Covid-19 salah satu kebijakan yang dilakukan pemerintah adalah memberikan bantuan langsung tunai kepada masyarakat selama pandemi Covid-19. Penggunaan dana desa untuk pencegahan dan penanganan dana Covid-19 tentu memiliki manfaat bagi masyarakat di dalam meningkatkan kualitas hidup ${ }^{3}$.

\footnotetext{
${ }^{3}$ Tengku Rika Valentine. Roni Ekha Putera. Cici Safitri. Analisis Pemanfaatan Dana Desa Pada Masa Pandemi Covid-19 Di Negeri Talang Anau Kabupaten Lima Puluh Kota. Vol. 2. 2020
} 
Adapun beberapa kebijakan yang dibuat pemerintah guna mengurangi penyebaran Covid-19 ini. Di antaranya adalah PSBB (Pembatasan Sosial Bersekala Besar), dan di Tahun 2021 ini muncul lagi kebijakan PPKM (Pemberlakuan Pembatasan Kegiatan Masyarakat. Hal ini menimbulkan perekonomian ataupun kebutuhan masyarakat menjadi menurun, disebabkan oleh Covid-19. Sehingga bantuan dari pemerintah maupun dari Desa di keluarkan secara akurat supaya kebutuhan masyarakat tidak terhalang hanya karena Covid-19. Salah satu bantuan dari desa ialah Bantuan Langsung Tunai (BLT) Dana Desa, ini bisa membantu masyarakat meringankan beban yang di alami, penyaluran Bantuan Langsung Tunai (BLT) Dana Desa, di berikan kepada masyarakat yang sangat membutuhkan terutama bagi masyarakat miskin dengan sejumlah dana Rp. 300.000. per bulan, akan tetapi bisa saja di berikan dengan jumlah 600.000 untuk dua bulan, itu tergantung banyak Dana Desa yang keluar.

Program Bantuan Langsung Tunai (BLT) ini beranjak dari Perpuu Nomor 1 Tahun 2020 Tentang Kebijakaan Keuangan Negara Dan Stabilitas Sistem Keuangan Untuk Penanganan Pandemi Covid-19 Dan/Atau Dalam Rangka Menghadapi Ancaman Yang Membahayakan Perekonomian Nasional Dan/Atau Stabilitas Sistem Keuangan, yang mengatur tetang penutamaan penggunaan dana desa untuk kegiatan tertentu. Makna pengutamaan penggunaan Dana Desa di sini di gunakan salah satunya untuk program bantuan langsung tunai kepada keluarga miskin di desa sebagai kegiatan penanganan dampak pandemic Covid-19. Penerima Bantuan Langsung Tunai (BLT) Dana Desa di berikan kepada keluarga miskin yang tidak menerima Bantuan Pangan Non Tunai (BPNT) dan tidak menerima Program Keluarga Harapan $(\mathrm{PKH})$ atau yang memiliki syarat yaitu kehilangan pekerjaan, terdapat keluarga yang rentan sakit menahun/kronis dan belum terdata ${ }^{4}$.

\section{Partisipatif Action}

Partisipatif action pendekatan ini di maksudkan untuk melihat, mendengar, sekaligus memahami gejala sosial yang ada di masyarakat. Gejala atau yang timbul di masyarakat sekarang akibat Covid-19 ialah perekonomian masyarakat menjadi menurun. Intruksi Presisen Joko Widodo untuk pemanfaatan anggaran Dana Desa, yakni anggaran tersebut harus dirasakan oleh seluruh warga di Indonesia dan dampak pembangunan desa harus lebih dirasakan melalui pembangunan desa yang terfokus. Di tengah pandemi Covid-19, anggaran Dana Desa dialihkan sebagian menjadi jaring pengaman sosial melalui program Bantuan Langsung Tunai (BLT) Dana Desa. Berikut kegiatan penyaluran Dana Desa berupa Bnatuan Langsung Tunai (BLT) Dana Desa:

\footnotetext{
${ }^{4}$ Ni Made Kitty Putri Suari. Ni Putu Niti Suari Giri. Analisis Terhadap Potensi Maladministrasi Bantuan Langsung Tunai (BLT) Dana Desa Selama Pandemi Covid-19. Jurnal Kertha Negara. Vol. 9 No. 2 Tahun 2021
} 


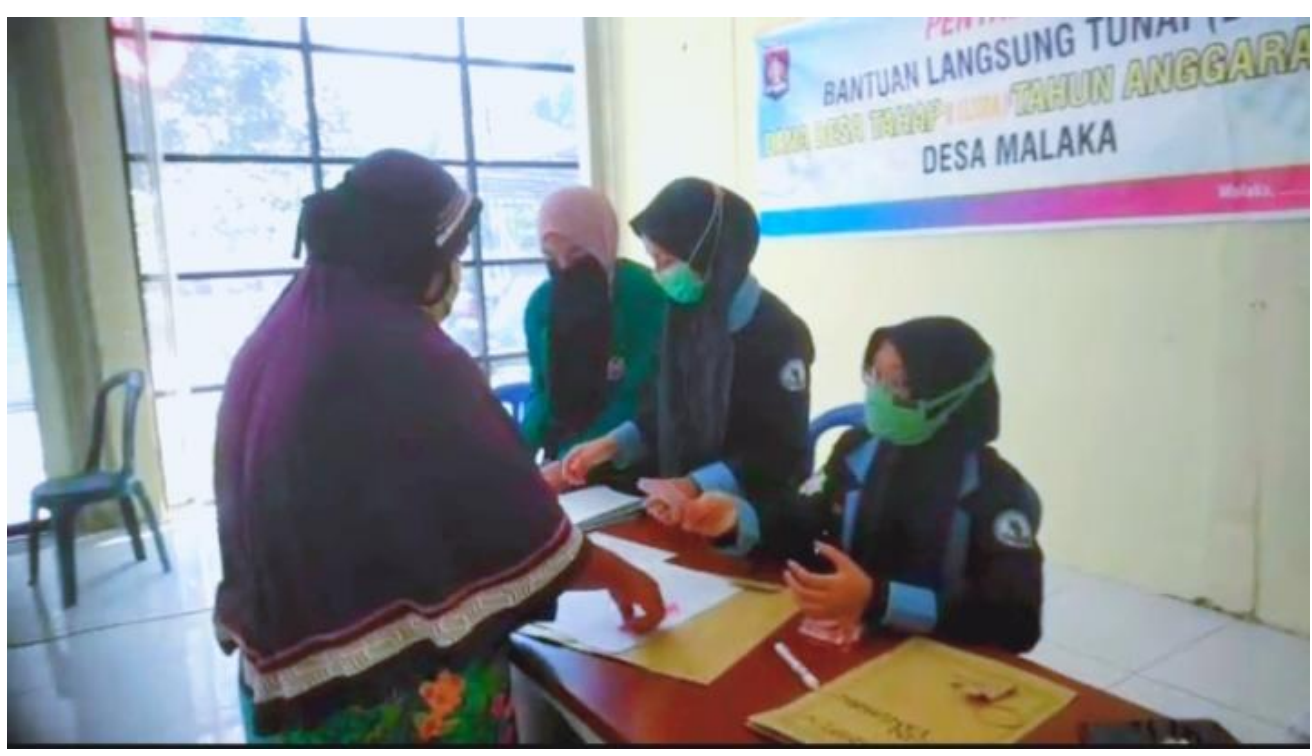

Gambar 1. Penyaluran Bantuan Langsung Tunai (BLT) Dana Desa ${ }^{5}$

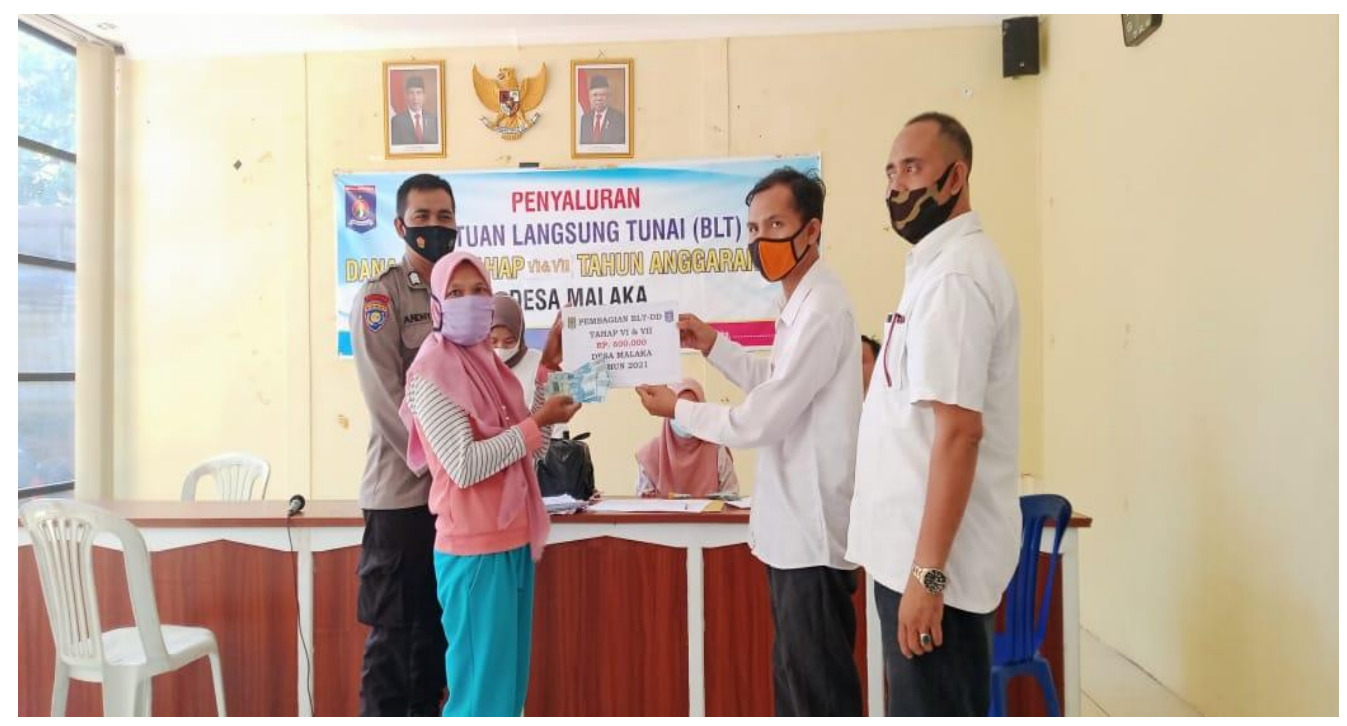

Gambar 2. Penyaluran Bantuan Langsung Tunai $(B L T)^{6}$

${ }^{5}$ Kegiatan Penyaluran Bantuan Langsung Tunai (BLT) Dana Desa Tahap V Tahun Anggaran 2021, Pada Hari Rabu, 14 Juli 2021 di Kantor Desa Malaka,Kecamatan Pemenang, Kabupaten Lombok Utara

${ }^{6}$ Kegiatan Penyaluran Bantuan Langsung Tunai (BLT) Dana Desa Tahap VI dan VII Tahun Anggara 2021, Pada Hari Rabu, 04 Agustus 2021 di Kantor Desa Malaka, Kecamatan Pemenang, Kabupaten Lombok Utara 


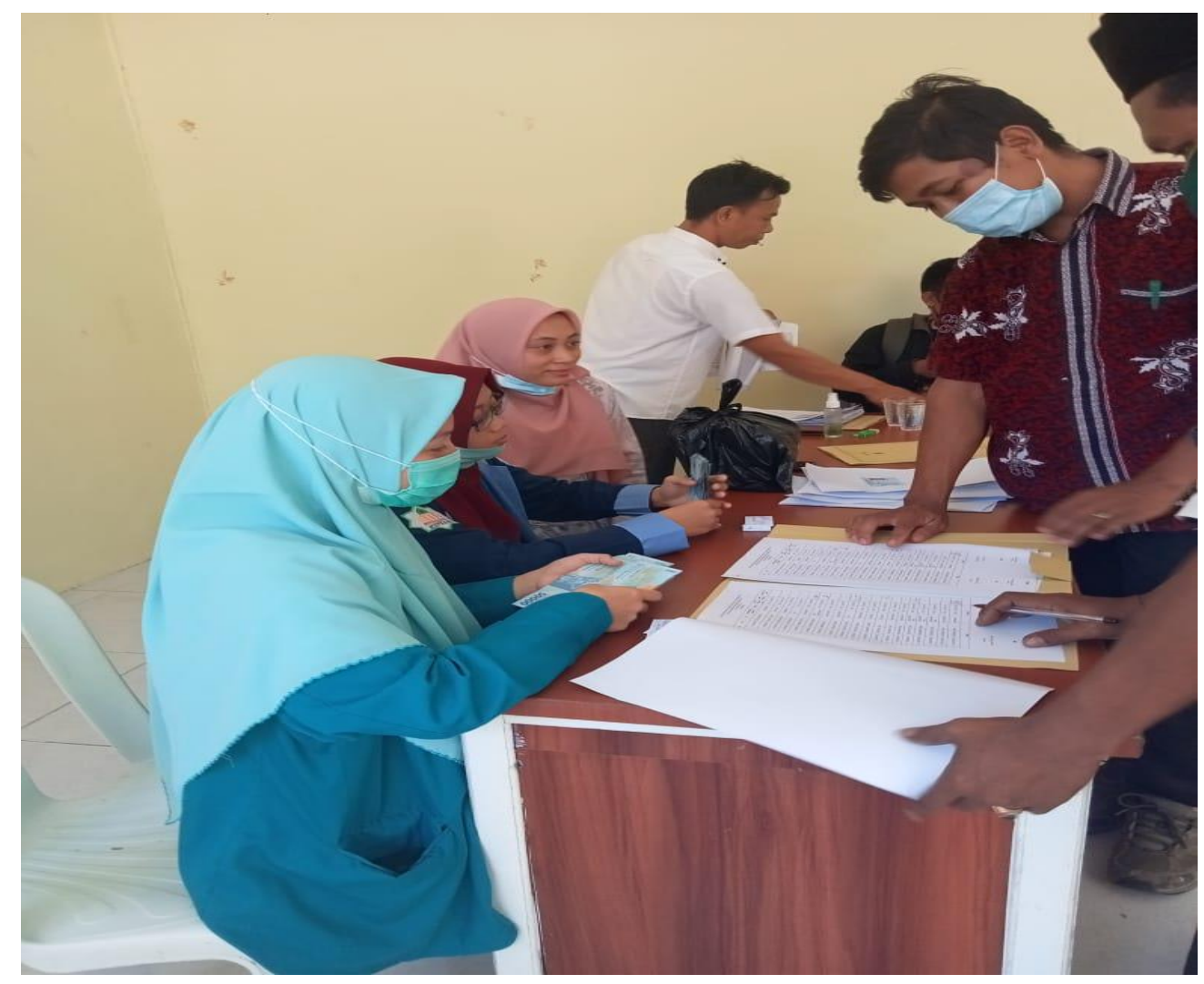

Gambar 3. Penyaluran Bantuan Langsung Tunai (BLT) Dana Desa ${ }^{7}$

Gambar di atas menerangkan penyaluran Bantuan Langsung Tunai (BLT) Dana Desa yang sasarannya merupakan masyarakat desa yang masih membutuhkan bantuan ekonomi seperti masyarakat miskin dan yang kehilangan mata pencaharian akibat Covid-19, masyarakat yang belum terdata pada kelompok penerima bantuan sosial lainnya, dan masyarakat yang memiliki anggota keluarga dengan sakit kronis.

Penyaluran Bantuan Langsung Tunai Dana Desa dilaksanakan oleh pemerintah dengan metode uang tunai per bulan. Penggunaan dana desa untuk pencegahan dan penanganan dana Covid-19 tentu memiliki manfaat yang besar bagi masyarakat dalam meningkatkan kualitas hidup masyarakat. Penyaluran Bantuan Langsung Tunai (BLT) Dana Desa dengan bertahap. Pada tahap V, masyarakat di berikan dana sebesar 300.000 per bulan begitu pun dengan penyaluran sebelum-sebelumnya, akan tetapi pada tahap VI dan VII masyarakat mendapat dana sebesar 600.000 untuk dua bulan, karena dana yang keluar dari desa untuk dua bulang langsung. Hal ini memberikan manfaat yang sangat besar bagi masyarakat atas bantuan yang di berikan oleh pemerintah.

\footnotetext{
${ }^{7}$ Kegiatan Penyaluran Bantuan Langsung Tunai (BLT) Dana Desa Tahap VI dan VII Tahun Anggaran 2021, Pada Hari Rabu, 04 Agustus 2021 di Kantor Desa Malaka, Kecamatan Pemenang, Kabupaten Lombok Utara
} 


\section{Wawancara}

Pandemi Corona Virus Diseases atau yang disingkat dengan Covid-19 belakangan ini membuat seluruh tatanan kehidupan sosial, dan ekonomi mengalami perubahan yang cukup signifikan. Pandemi ini tidak hanya berdampak pada kesehatan, melainkan juga menekan perekonomian dari berbagai sudut, tidak terkecuali terhadap perekonomian desa. Upaya-upaya yang dilakukan oleh pemerintah untuk mencegah dan menanggulangi perekonomian ditingkat desa salah satunya adalah dengan pemanfaatan dana desa ${ }^{8}$.

Menyebarnya Covid-19 keseluruh dunia, khususnya Indonesia membawa dampak pada perekonomian Indonesia, dimana sejak adanya virus ini masyarakat dihimbau untuk mengurangi aktivitas diluar rumah, sector pariwisata harus ditutup, jadwal penerbangan dan transportasi lain dikurangi, beberapa terminal ditutup, beberapa pabrik dan perusahaan melakukan lockdown, dan berbagai hal lain yang menyebabkan perekonomian Indonesia lumpuh.

Namun saat ini Indonesia memasuki era baru, yaitu era new normal (normal baru), dimana pada era ini masyarakat sudah bisa beraktifitas seperti biasa, namun harus mengikuti protokol kesehatan. Protokol kesehatan yang dimaksud adalah masyarakat wajib menggunakan masker, jaga jarak sejauh 1 (satu) meter, rajin mencuci tangan, dan di larang berkerumunan. Meskipun demikian, perekonomiam Indonesia tidak bisa pulih dengan cepat, karena kenyataannya Covid19 masih bertebaran disekitar masyarakat, dan aktivitas masyarakat dibatasi. Dengan hal itu, pemerintah merancang kebijakan untuk menekan penyebaran dan penanganan virus ini. Salah satunya penyebab Covid-19 ini ialah perekonomian menjadi menurun, sehinga pemerintah memberikan bantuan kepada masyarakat melalui Dana Desa, seperti Bantuan Langsung Tunai (BLT) Dana Desa untuk diberikan kepada masyarakat miskin.

\footnotetext{
${ }^{8}$ Nuniek Dewi Pramanik. Dampak Bantuan Paket Sembako Dan Bantuan Langsung Tunai Terhadap Kelangsungan Hidup Masyarakat Padalarang Pada Masa Pandemi Covid 19. Intelektiva: Jurnal Ekonomi, Sosial dan Humaniora. Vol. 01 No. 12. Juli 2020
} 


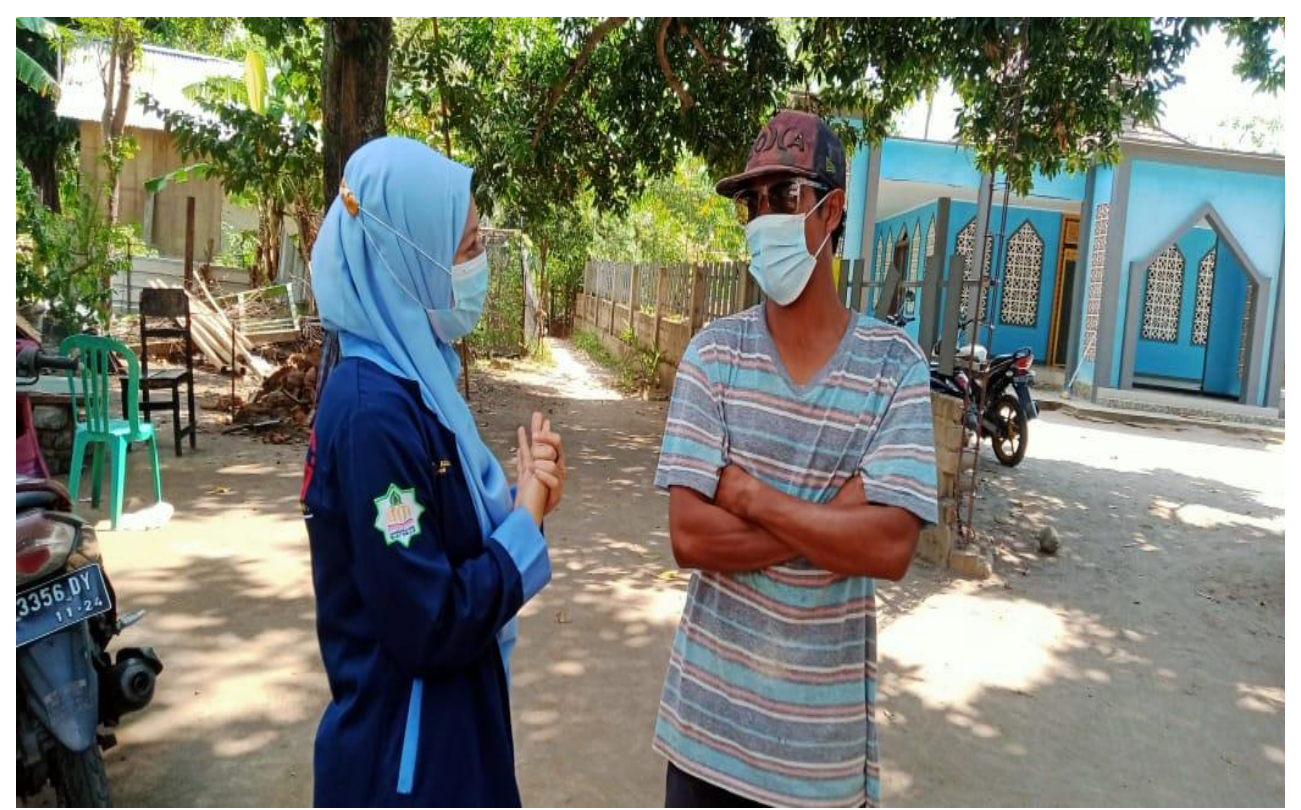

Gambar 4. Wawancara penerima BLT ${ }^{9}$

Bantuan Langsung Tunai (BLT) sangat bermanfaat bagi masyarakat "bantuan ini bisa di gunakan untuk membayar beras, membiayai anak sekolah dan untuk kebutuhan lainnya" ujar Bapak Samsul Idris, anggota masyarakat Dusun Pandanan, Desa Malaka yang menerima Bantuan Langsung Tunai (BLT) Dana Desa.

\section{Kesimpulan}

Setelah melakukan pengabdian, maka pengabdi dapat menyimpulkan bahwa Covid-19 hadir pada akhir tahun 2019, pada tahun ini banyak sekali kejutan yang didapatkan oleh semua Negara di seluruh belahan dunia. Hal ini disebabkan menyebarnya wabah penyakit bernama Covid-19 yang mulai berkembang di Wuhan, Negara Cina. World Health Organization (WHO) menyatakan wabah penyebaran virus ini sebagai pandemic dunia saat ini. Hal ini juga dialami oleh Negara Indonesia.

Ada beberapa kebijakan yang dilakukan pemerintah guna mengurangi penyebaran Covid19 ini. Di antaranya adalah, PSBB (Pembatasan Sosial Bersekala Besar) dan di tahun 2021 ini muncul lagi kebijakan PPKM (Pemberlakuan Pembatasan Kegiatan Masyarakat). Hal ini juga menimbulakan perekonomian masyarakat menajdi menurun sehingga pemerintah merancang kebijakan untuk mengurangi beban kehidupan masyarakat dengan memberikan bantuan seperti

\footnotetext{
${ }^{9}$ Kegiatan wawancara Masyarakat Penerima Bantuan Langsung Tunai (BLT) Dana Desa, Pada Hari Kamis, 05 Agustus 2021 Mengenai Dampak Bantuan Langsung Tunai Bagi Masyarakat Desa Malaka, Kecamatan Pemenang, Kabupaten Lombok Utara
} 
bantuan dari desa, salah satunya ialah Bantuan Langsung Tunai (BLT) Dana Desa, bantuan ini setidaknya bisa membantu kehidupan masyarakat yang sangat membutuhkannya terutama masyarakat miskin. Penggunaan dana ini diberikan kepada masyarakat miskin, supaya merasakan kemanfaatan dari dana tersebut dalam menjalani keberlansungan Covid-19 ini.

Bantuan langsung tunai (BLT) Dana Desa sangat bermanfaat bagi masyarakat karena bisa digunakan untuk menunjang hidup selama pandemic Covid-19 ini, terutama untuk masyarakat miskin dan masyarakat yang mempunyai penyakit kronis, bantuan tersebut bisa digunakan untuk berobat dan kebutuhan-kebutuhan lainnya seperti membeli beras, membiayai anak sekolah dan lain-lain.

\section{Ucapan Terima Kasih}

Pengabdi mengucapkan terima kasih kepada kepala LP2M UIN Mataram atas terselanggaranya kegiatan KKP-DR 2021 dengan lancar. Serta seluruh masyarakat yang ada di Desa Malaka yang telah ikut serta membantu dan mendukung kegiatan Mahasiswa UIN Mataram yang sedang melakukan kegiatan pengabdian terlaksa sesuai dengan yang di rencanakan dan dampaknya dirasakan langsung oleh masyarakat. Dan terima kasih juga kepada DPL yang telah membimbing kami untuk melaksanakan KKP-DR di Desa kami dengan sengat akurat dan detaildetailnya mengenai KKP-DR ini. Dan yang terakhir untuk team KKP-DR UIN Mataram yang telah ikut mengidentifikasi seluruh masalah yang ada di desa terutama masalah perekonomian yang menurun di sebabkan pandemi Covid-19, serta kegiatan-kegiatan yang lain terlaksana dengan lancar, sehingga dalam artikel ini tersedia informasi yang valid dan sesuai tentang dampak Bantuan Langsung Tunai (BLT) bagi masyarakat akibat Covid-19 di Desa Malaka Kecamatan Pemenang Kabupaten Lombok Utara.

\section{Daftar Pustaka}

Pramanik, Nuniek Dewi. 2020. Dampak Bantuan Paket Sembako Dan Bantuan Langsung Tunai Terhadap Kelangsungan Hidup Masyarakat Padalarang Pada Masa Pandemi Covid 19. Intelektiva: Jurnal Ekonomi, Sosial dan Humaniora. Vol. 01 No. 12. Juli 2020

Prasetyandari, Cici Widya. 2021. Dampak Covid-19 Bagi Roda Perekonomian Bagi Masyarakat Indonesia. Jurnal Imagine. Vol. 1 No. 1. April 2021

Selviana. 2016. Bantuan Langsung Tunai. Jurnal Equilibrium Pendidikan Sosiologi. Vol. III No. 2. November 2016

Kemendes PDTT. 2020. Panduan Pendataan Bantaun Langsung Tunai-Dana Desa (BLT-Dana Desa). Jakarta 
Herdiana, Dian. Wahidah, Idah. Nuraeni, Neni. Salam, Annisa N. 2021. Implementasi Kebijakan Bantuan Lansung Tunai (BLT) Dana Desa Bagi Masyarakat Terdampak Covid-19 di Kabupaten Sumedang: Isu dan Tantangan. Jurnal Inspirasi. Vol 12 No. 12021

Valentine, Tengku Rika. Putera, Roni Ekha. Safitri, Cici. 2020. Analisis Pemanfaatan Dana Desa Pada Masa Pandemi Covid-19 Di Negeri Talang Anau Kabupaten Lima Pulub Kota. Vol. 2. 2020

Suari, Ni Made Kitty Putri. Giri, Ni Putu Niti Suari. 2021. Analisin Terhadap Potensi Maladministrasi Bantuan Langsung Tunai (BLT) Dana Desa Selama Pandemi Covid-19. Jurnal Kertha Negara. Vol. 9 No. 2 Tahun 2021 